\title{
Employee Engagement Toward Intention To Quit With job Insecurity As Moderating Variable At Goverment Bank In Bandung City
}

\author{
Deddy Rusyandi \\ derusy@gmail.com,deddy.rusyandi@ekuitas.ac.id
}

\begin{abstract}
The purpose of this research was to demonstrate the importance of employee engagement and its relationship to employee intent to quit witch moderated by job insecurity on employees frontline state bank in Bandung City Indonesia. The method used is explanatory survey method that this study took a sample of the population with a questionnaire and interview techniques as the primary means of data collection. The subjects of the study were also as the unit of analysis in this study is the frontline employees (teller and customer service) that serve the general customers, where the position is vulnerable to employee turnover, whereas they are the spearhead or the forefront (frontline) that connects to the customer's bank (the customer ). A randomly selected sample of 4 bank was used in this study. A total of 270 respondents participated. Data were analyzed using Smart PLS 2.0. The linear regression analysis indicated there was a significant, strong, and negative linear relationship between employee engagement level and employee intent to quit rate. The results of this research promote employee engagement is a significant negative effect amounted $41,42 \%$ of the intention to quit, while the variable job insecurity is not proven significantly. The conclusion from this study is that the employe engagement give significant influence on the intention to quit and variable job insecurity is not a variable moderation.
\end{abstract}

Keywords: ; bandung, banking sector, engagement, frontliner, Intention to quit, job insecurity.

\section{INTRODUCTION}

\subsection{Background}

Intention to quit either completely quit would also change job is a major concern for companies because when employees do not mind in the organization, concentration and motivation will be lost and this would reduce the productivity and efficiency of the organization. Many things that cause employees intend to get out of the workplace, such as: feelings of employees who feel that the organization is no longer able to meet their needs. they show indications of declining productivity levels will have an impact on the disruption of corporate activity, such as increased absenteeism, less excited and led to a decline in performance, whereas high employee performance have a positive impact in achieving the goals of the orhuiganization (company), as it reflects the productivity of the organization which reflects the ability of employees to achieve the objectives as planned (Nusair, 2013). Another effect is likely to cause problems morale of the other employees that bandwagon have no intention to leave the company.

HR managers should be able to suppress the employees intention to quit or leave the company by creating conditions that may encourage employees to feel at home and want to remain in the organization. Some research reveals that employees are engaged make employees are emotionally tied to their organization, and will become more passionate with his work (Balakrishnan, 2013). According Gallup (2005) "employee are dedicated to their role, will stay in the organisation for a long time, more productive, give better customer service and in turn create greater profit..." Increasing employee engagement will encourage them to higher performance, as said Crim and Seijts (2006) that employee engagement is "a person who is fully involved in, and enthusiastic about his or her work. Engaged employees care about the future of the company and are willing to invest the discretionary effort to see that the organization succeeds".

Have employees who fully engagement is very advantageous for the company, because they will stay longer in the organization and productive indefinitely so that the company can avoid the high turnover. However, organizations should be aware that different engagement with the commitment, as said by Thomas Britt, a professor of industrial psychology at Clemson University, says that "a worker can be engaged but not committed". employee engagement is a person who invests herself in superior job performance, while employees who committed are a psychological attachment to a worker in the organization. Although very productive, they might be more susceptible to the frustration of negative factors at work, such as budget cuts, inadequate supplies and equipment, there is no reward for being successful, and a salary that does not match the performance. They become frustrated and likely want or intend to quit or leave of their company to seek opportunities in other companies (http://stephenjgill. typepad.com/).

Intention to quit many suffered employees in the banking sector Bandung, which currently has assets of Conventional Bank reached Rp 156.77 trillion. With the number of banks to 47 banks (http://www.tempo.co/ 
read/news/ 2013) including the State Bank. The growth of the banking industry in the city is due to the assumption that Bandung is a city that has potential in the field of creative industries, businesses culinary, fashion, crafts, and education, in addition to being a tourist destination both natural attractions and cultural tourism are supported by strong interest the tourists to visit the city of Bandung both local or foreign.

The growing of bank in Bandung had an impact on increasing competition. Banks are constantly striving to improve service to they customers, which is become the spearhead are frontline employees, which is precisely that generally often feel the intent to quit. This is due to lack of attention to the bank, but their presence is very important as a link between companies and customers and also as a source of information for customers and prospective customers. They also charged a target in selling bank products, recruit new customer or account opening are widely between $50-100$. The realization of the intentions of the exit is the turnover, and turnover of employees of banks in Indonesia reached 20\% a year (http: // economy. okezone.com/read/ 2013 /; Awaldi, 2014).

So far the data bank employee turnover in Bandung can not be found, but the results of interviews with frontline employees at some bank in Bandung, such as: PT. BJB, Bank Sinar Mas, Bukopin, BNI and BCA can be estimated that there are at least two of their friends have done resign (resignation) this year, while new bank intends to get out of where they work at least 4 people and some of them are self their own, and according to them this condition is almost the case also in several branch offices and other branches.

The number of employees who outgoing and who intend to quit showing that the bank employee engagement index is low. This is demonstrated by the low engagement services to customers who do not wholeheartedly and soul, they will only serve merely transactional only with smiles and hospitality that seem insincere. Another impact is the decline in their performance shown by their frequent cut salaries because of the differences between records of transactions that occurred with the evidence received.

From observations and interviews with several employees frontline bank in Bandung can be seen that the level of absenteeism and late coming to work is quite high, namely 6 and 8 times in every month, often complain when doing work outside the duties or when facing customer complaints, less enthusiastic about the job and the willingness to work overtime was due to the incentive overtime instead of having to finish the job.

Demands engagement to the frontline employees will be difficult given the status of their work is generally contracts or workers with Work Agreement Specific Time (PKWT). Workers with contract status has no guarantee to be able to work continuously in the organization, because when the contract is completed then finished on the relation of the workers with organsiasi. Although there is a possibility that the contract period is extended, but that is only 1 or 2 times extension. Contract status on frontline employees have sparked job insecurity, which is a general fear of the sustainability of their work at the bank where they worked. The emergence of job insecurity on the frontline employees will certainly reinforce the lack of engagement of employees frontline against the bank where they worked.

\subsection{Problem}

Based on the background, the research problems can be formulated as follows:

1. How does the influence frontline employee engagement toward the intention to quit the government bank in Bandung.

2. How does influence employee engagement frontline toward the intention to quit the government bank in the city of Bandung after moderated job insecurity.

\subsection{Purposes}

based on the research problem, the purpose of this study was to explore and examine and analyze the following things:

1. Effect of employee engagement frontline against the intention to quit the government bank in Bandung.

2. Effect of employee engagement frontline against the intention to quit the government bank in the city of Bandung after the affected job insecurity.

\section{LITERATURE, FRAMEWORK AND HYPOTHESES}

\subsection{Literature}

\subsubsection{Employee Engagement}

Until now there is no generally accepted definition of employee engagement, as stated by Markos and Sridevi (2010)," "To date, there is no generally accepted definition for employee engagement. However, there is growing consensus among the authors that the construct is distinguishable from related concepts in management such as employee commitment, organizational citizenship behaviour and job satisfaction in such a manner that employee engagement clearly reflects the two-way exchange of effort between employees and employers, and it has stretched meaning beyond the aforementioned constructs". But according to them, construct employee engagement is distinguished from the concept of commitment, OCB and satisfaction, employee engagement reflects efforts where two-way exchange between the employee and the employer.

of some of the definitions expressed by researchers such as Markos and Sridevi (2010); Seijts and Crim (2006); Lockwood (2007); Wegner (2011); Robinson et al. (2004); Gallup organization (2004); and Robin (2012) can be made a construct, that the attachment of employee engagement is a "positive attitude that employees have to work, which is reflected in the enthusiasm, satisfaction and fully engaged with their work, they feel as an integral part of the organization in achieving its mission, which makes them willing to work harder with colleagues and give discretionary effort (exceeding standards) in helping achieve the goals of the organization ". 


\subsubsection{Intention To Quit}

Intention can be interpreted as an the purpose arising from oneself towards something. When someone has the intention then it is likely he will do so. Khan (2013), referring to the earlier researchers explained that the intention is the most direct determinant of actual behavior. Therefore intention to quit is defined as the forerunner (embrio) to a complete stop from a particular job. Correspondingly Makhbul, et al (2011) also explains that the intention is to stop the manifestation of actual turnover.

Some researchers like Balogun. et al (2013), Windya (2013), Schalkwyk et al. (2010), Mxenge, et al. (2014) found intention to quit is the intent of the employee to quit his job either completely stopped or even moved to another company in the near future due to individual factors like any organization.

\subsubsection{Job Insecurity}

Job insecurity is a concern over the safety of employees in continuing their work in the company, these conditions will have an impact or influence the level of job satisfaction, organizational commitment, and trust in the organization. Further impacts are employees will seek other employment alternatives outside the company. However, the actual definition of job insecurity is defined differently by each researcher, as presented by Banu. et al. (2012) which explains that job insecurity is defined by researchers in different ways, but in essence the perception of job insecurity is a "subjective" experienced directly by employees.

Banu et al. (2012) and Bosman (2005) classifies job insecurity in perspective "subjective" and "objective", while Adenugba, et al. (2012), subsume job insecurity perspective that is "global" and "multidimensional", whereas Peene (2009) classifies job insecurity in perspective "quantitative" and "qualitative". But in essence they are defined job insecurity as feeling worried about the threat of losing jobs now, and helplessness in maintaining the employment. So therefore developed a construct that job insecurity (job insecurity) is a good feeling based on sujektif or on kekhawatirian against the threat of losing jobs now, and helplessness in maintaining the employment.

\subsubsection{Framework}

Every company including Banks wants theys employees to have a high performance, because the performance of employees as reflects the productivity of the company that reflects the employee's ability to achieve the objectives as planned, however, seems to be difficult when employees wish or intent to quit or get out of the company. Intenton to quit or intention to leave or employee turnover intention is intent to quit or get out of the company caused by factors individuals and organizations in which they work. The phenomenon of intention to quit often experienced by employees of the bank employees, especially frontline. This is demonstrated by the high level of turnover in the banking sector. Turnover is a manifestation of intenton to quit / intention to leave / turnover intention. Intention to quit this bad for the company, because employees who have the intention quit a could have negative impact on productivity and employee performance.

Some researchers say that having employees that engagement is a tremendous advantage for the company, because engagement employees will stay longer in the organization. Employees engagement always be positive, as reflected in the enthusiasm, satisfaction and fully engaged with their work, they feel as an integral part of the organization in achieving its mission, which makes them willing to work harder with colleagues and give discretionary effort (exceeding standards) in helping achieve organizational goals. Having employees engagement can increase the company's efforts in retaining employees, especially potential employees.

Some literature and studies reveal employee engagement can reduce employee intent to quit, can further reduce the level of turnover. Potential employees are engaged to be loyal to the company so they choose to remain in the organization on the basis of their confidence in the organization within the maximum time. The existence of potential employees in the organization will have an impact on the company's performance as reflected by the performance of employees.

However, this level of engagement could be decreased when employees feel that their job or position in the organization is threatened, or in other words they do not secure jobs (job insecurity). Employees who feel that job insecurity will try to find another job elsewhere that is felt more secure. This means that attachment and commitment will certainly go down or even disappear when employees feel threatened.

Frontline bank employees wants to be continue in the bank where they worked, worked diligently and earnestly, but in fact they are generally only contract status and the possibility to become permanent employees is quite small. This contract status creates uncertainty on the sustainability of their work, whether the contract is extended or not? This uncertainty encourages the emergence of insecurity in their jobs.

The problems it interesting to study given that intent quit can interfere with the performance of employees. Intention of stopping can be reduced through employee engagement, but the advent of job insecurity is likely to reduce the level of employee engagement. Based on the framework above, this research paradigm can be described described as shown below.

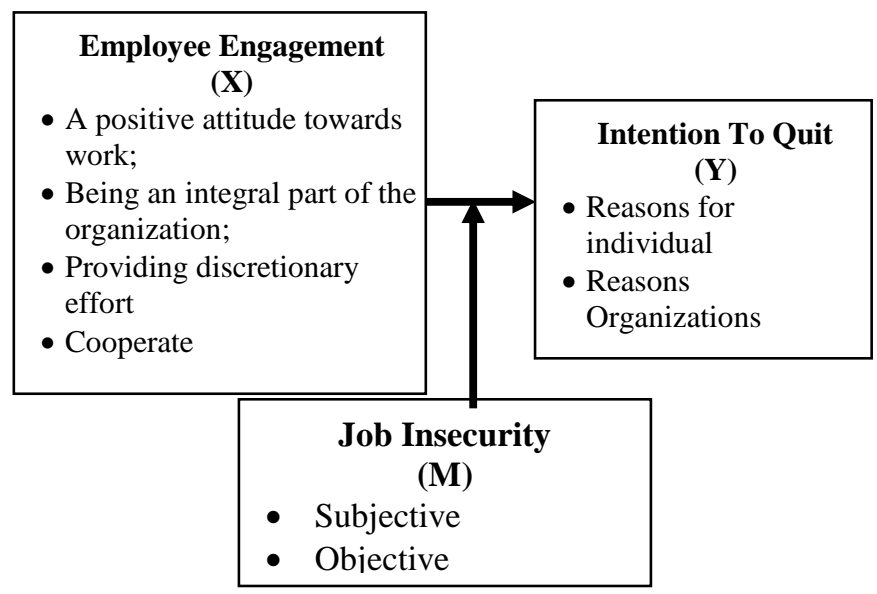

Figure 1. Paradigm 
Figure 1. Paradigm

\subsubsection{Hypotheses}

Based on the above framework, the research hypothesis can be formulated as follows:

1. Employee engagement negatively affect the intention to quit at the frontline employees of government banks in Bandung.

2. The effect of reduced employee engagement against the intention to quit at the frontline employees of state banks in the city of Bandung after moderated job insecurity.

\section{RESEARCH METHODS}

\subsection{Methods}

This type of research is verification because this research aims to explore and analyze the variables employee engagement, job insecurity, and intention to quit. employee engagement Variable is a predictor variables (independent), while ob insecurity is moderators variable can streng then or weaken the predictor variable, while the dependent variable, namely the intention to quit on a number of government bank in Bandung.

The method used is explanatory survey method that this study took a sample of the population with a questionnaire and interview techniques as the primary means of data collection.

The subjects of the study were also as the unit of analysis in this study is the frontline employees (teller and customer service) that serve the general customers, where the position is vulnerable to employee turnover, whereas they are the spearhead or the forefront (frontline) that connects to the customer's bank (the customer ).

\subsection{Operationalization Of Variables}

Untuk lebih menjelaskan variabel-variabel yang digunakan dalam penelitian ini maka kelima variabel tersebut ditabulasikan dalam tabel Operasionalisasi variabel penelitian seperti tabel 9 berikut ini:

Table 1.

Variable Operationalization

\begin{tabular}{|c|c|c|}
\hline $\begin{array}{l}\text { Variable / } \\
\text { Concept }\end{array}$ & Dimensions & Indicator \\
\hline \multirow{6}{*}{$\begin{array}{c}\text { Employee } \\
\text { Engagement } \\
\text { (X) }\end{array}$} & \multirow{3}{*}{$\begin{array}{l}\text { A positive } \\
\text { attitude } \\
\text { toward work }\end{array}$} & Enthusiastic on the job \\
\hline & & job satisfaction \\
\hline & & $\begin{array}{l}\text { Fully engaged with the } \\
\text { work }\end{array}$ \\
\hline & \multirow{3}{*}{$\begin{array}{l}\text { Become an } \\
\text { integral part of } \\
\text { the } \\
\text { organization }\end{array}$} & work hard \\
\hline & & working together \\
\hline & & discretionary effort \\
\hline \multirow{3}{*}{$\begin{array}{c}\text { Job } \\
\text { Insecurity } \\
\text { (M) }\end{array}$} & \multirow{3}{*}{ subjective } & promotion \\
\hline & & work \\
\hline & & income \\
\hline
\end{tabular}

\begin{tabular}{|c|c|c|}
\hline & & $\begin{array}{l}\text { Employment } \\
\text { Opportunities }\end{array}$ \\
\hline & \multirow{3}{*}{ Candid } & Government Policy \\
\hline & & Company Policy \\
\hline & & Environmental Change \\
\hline \multirow{10}{*}{$\begin{array}{c}\text { Intention } \\
\text { To Quit) } \\
\quad(\mathbf{Y})\end{array}$} & \multirow{5}{*}{$\begin{array}{l}\text { reasons } \\
\text { Individuals }\end{array}$} & Unable to work \\
\hline & & family \\
\hline & & Bored an employee \\
\hline & & Not animates the work \\
\hline & & Got a better job offer \\
\hline & \multirow{5}{*}{$\begin{array}{l}\text { reason } \\
\text { organizations }\end{array}$} & $\begin{array}{l}\text { Working under } \\
\text { pressure }\end{array}$ \\
\hline & & salary policy \\
\hline & & $\begin{array}{l}\text { Work atmosphere is } \\
\text { not conducive }\end{array}$ \\
\hline & & Not a promising future \\
\hline & & No challenge \\
\hline
\end{tabular}

\subsection{Source And Determine Data}

The data required in this research consisted of primary data and secondary data. The subjects of this study were employees of the frontline (teller and customer service) at the government banks working in the branch office (KC) and Branch Office (KCP) in Bandung. The total number of employees working at the front liners $\mathrm{KC} \mathrm{KCP}$ Bank and the government of Bandung, Bank Mandiri PT Persero Tbk amounted to 238 employees, Bank Negara Indonesia PT Persero Tbk 300 employees, 82 employees of the State Savings Bank and Bank Rakyat Indonesia 182 employees, thus the number of bank employees government in the city of Bandung is 802 employees. To determine the number of samples used is determined by using purposive sampling using Slovin formula:

$$
\mathbf{n}=\mathbf{N} /\left(\mathbf{1}+\mathbf{N}(\mathbf{e})^{2}\right. \text {. }
$$

With a $95 \%$ degree of confidence, then obtained a minimum sample size of $\mathrm{n}=802 /(1+802(5 \%) 2)$ or $\mathrm{n}$ $=266.89$. Thus, the required minimum sample in this study were 267 frontline employees.

\subsection{Data Collection Technique}

Data yang digunakan untuk menjawab masalah yang telah dirumuskan diperoleh dengan menggunakan teknik Studi Kepustakaan (Library Research) dan Studi Lapangan (Field Research) serta observasi pada perusahaan yang bersangkutan, melalui cara Wawancara, Observasi dan Kuesioner.

\subsection{Design of Analysis and Testing Hypotheses}

The primary data used in this study need to be tested validity and reliability because the data is derived from the respondents that may lead to bias. The method of analysis used to answer the problems that have been formulated in this study. As noted earlier that this kind of research is verification, so the design of this study is verification with the aim of presenting a picture in a structured, factual and accurate and empirically test the hypothesis by using statistical analysis tools, namely PLS (Partial Least Square) by using software SmartPLS version 2.0. 


\section{BAB IV \\ PEMBAHASAN}

\subsection{Pengujian Validitas dan Reliabilitas}

An indicator declared invalid if it has loading factor above 0.5 to construct the destination. Output SmartPLS for loading factor below 0.5 results for several indicators of questions. Invalid indicators are removed from the model, so that the number of indicators which was originally 53 to 24 are valid.

Another method to see the discriminant validity is to look at the value of the square root of average variance extracted (AVE). Recommended value is above 0.5 . Here is the value AVE in this study:

Table 2

\begin{tabular}{|l|c|}
\hline \multicolumn{2}{|c|}{ AVE } \\
\hline ENG & 0,525541 \\
\hline ENG * JIS & 0,558505 \\
\hline ITQ & 0,514825 \\
\hline JIS & 0,547808 \\
\hline
\end{tabular}

Sementara Uji reliabilitas dilakukan dengan melihat nilai composite reliability dari blok indikator yang mengukur konstruk. Hasil composite reliability akan menunjukkan nilai yang memuaskan jika di atas 0,7 . Berikut adalah nilai composite reliability pada output:

Table 3

\begin{tabular}{|l|l|c|c|l|}
\hline & $\begin{array}{l}\text { Composite } \\
\text { Reliability }\end{array}$ & $\begin{array}{c}\text { Commu- } \\
\text { nality }\end{array}$ & $\begin{array}{c}\text { Cronbachs } \\
\text { Alpha }\end{array}$ & $\begin{array}{l}\text { Redun- } \\
\text { dancy }\end{array}$ \\
\hline ENG & 0,914520 & 0,315704 & 0,799389 & \\
\hline ENG*JIS & 0,986726 & 0,297790 & 0,989282 & \\
\hline ITQ & 0,892041 & 0,258497 & 0,840852 & 0,161610 \\
\hline JIS & 0,877024 & 0,300334 & 0,818753 & \\
\hline
\end{tabular}

The table shows that the composite reliability values for all constructs are above 0.7 indicating that all construct at the model that meets the criteria of discriminant validity estimated. Composite reliability of the lowest value is equal to 0.877024 at the construct of JIS (Jobinsecurity).

Reliability test can also be strengthened by Cronbach's Alpha, communality values at the all CONSTRUCTS above 0.5 which reinforces the results of testing with Composite Reliability and Cronbach's Alpha. Furthermore, the value of ITQ Redundancy is equal to 0.403786 which includes high. Recommended value is above 0.6 and at the above table shows that the value of Cronbach's Alpha for all CONSTRUCTS be above 0.6. The lowest value is equal to 0.799389 (Eng / Engagement).

\subsection{Pengujian Hipotesis}

\section{Table 4}

\begin{tabular}{|c|c|c|c|}
\hline & $\begin{array}{c}\text { Original } \\
\text { Sample }(\mathrm{O})\end{array}$ & $\begin{array}{c}\text { Sample Mean } \\
(\mathrm{M})\end{array}$ & $\begin{array}{c}\text { Standard } \\
\text { Deviation } \\
(\text { STDEV })\end{array}$ \\
\hline
\end{tabular}

\begin{tabular}{|l|c|c|c|}
\hline ENG -> ITQ & $-0,414224$ & 0,418226 & 0,136914 \\
\hline $\begin{array}{l}\text { ENG * JIS -> } \\
\text { ITQ }\end{array}$ & $-0,187671$ & $-0,204135$ & 0,241621 \\
\hline JIS -> ITQ & 0,791538 & 0,801869 & 0,154929 \\
\hline
\end{tabular}

\begin{tabular}{|c|c|}
\hline $\begin{array}{c}\text { Standard } \\
\text { Error } \\
(\text { STERR })\end{array}$ & $\begin{array}{c}\text { T Statistics } \\
(|\mathrm{O} / \mathrm{STERR}|)\end{array}$ \\
\hline 0,136914 & 3,025429 \\
\hline 0,241621 & 0,776718 \\
\hline 0,154929 & 5,109037 \\
\hline
\end{tabular}

Coefficient parameter lines derived from the relationship between the variables engagement with intention to quit amounted to -0.414 with $\mathrm{T}$-statistic values $3.0254>1.65$ at significance level $\alpha=0.1$ which states that there is a significant relationship between engagement with the intention to quit, Negative values on parameter coefficient means that the higher the level of engagement, the desire to get out / move (intention to quit) will decrease.

Coefficient parameter lines derived from the relationship between the variables Job insecurity and intention to quit obtained at 0.791538 to the value of the T-statistic 5.109037> 1.64

at significance level $\alpha=0.1$ which states that there is a significant positive effect. meaning that the higher the higher the job insecurity desire to exit / moving work (intention to quit).

Based on the table it can be seen that the value of $\mathrm{T}$ statistics obtained in the variable Moderation (engagement * Jobinsecurity) amounted to 0.776718 $<1.65$, at significance level $\alpha=0.1$ which means that the variable was not statistically significant moderation.

Once the model is estimated meets the criteria Outer Model, subsequent testing of structural models (Inner model). Here is the value of R-Square at the construct:

Table 5

\begin{tabular}{|l|l|}
\hline \multicolumn{2}{|c|}{ R Square } \\
\hline Engage & \\
\hline Engage * JIS & \\
\hline ITQ & 0,732886 \\
\hline JIS & \\
\hline
\end{tabular}

The table above gives the value of 0.732886 to construct ITQ (intention to quit), which means at the ITQ is affected by the disengagement (engagement), JIS (job insecurity) and moderation (JIS * engage) in the amount of $73.7027 \%$.

\section{CONCLUSION}

1. Analysis of structural equation model at the the case of latent variables influence engagement toward the 
intention to quit frontline employees of state banks in Bandung is obtained as follows:

a. There is a negative influence between the engagement of the intention to quit amounted to $41.42 \%$.

b. b. There is a positive influence between job insecurity to the intention to quit amounted to $79.15 \%$.

2. Analysis of structural equation model with moderation Infrastructure in the case of latent Job insecurity as a moderating influence engagement intention to quit, is that the variable job insecurity not as a moderator variable.

\section{REFERENCES}

Abraham, Susan. 2012. Job Satisfaction as an Antecedent to Employee engagement. SIES Journal of Management 8.2. (Sep 2012): 27-36.

Adenugba, Adebimpe A., Oteyowo, Odunayo. 2012. Job Insecurity in Selected Banks in Ibadan Southwest Nigeria. ISSN 2039-2117 Mediterranean Journal of Social Sciences

Vol. 3 (2) May 2012

Agyemang, Collins Badu, Ofei, Samuel Batchison. 2013. Employee Work Engagement And Organizational Commitment: A Comparative Study Of Private And Public Sector Organizations In Ghana. European Journal of Business and Innovation Research Vol.1, No.4, pp.20-33, December 2013

Akpan, C. P. 2013. Job Security And Job Satisfaction As Determinants Of Organizational Commitment Among University Teachers In Cross River State, Nigeria. British Journal of Education Vol.1, No.2, pp. 82-93, December 2013

Awaldi. 2014. Karyawan Galau, Nasabah Selingkuh. Infobank No 418, Januari 2014, Vol. XXXV.

Balakrishnan, C; Masthan, D and Chandra, V. 2013. Employee Retention Through Employee Engagement - A Study At An Indian International Airport. International Journal of Business and Management Invention ISSN (Online): 2319 8028, ISSN (Print): 2319 - 801X.

Benjamin Olabimitan, A., Ilevbare Femi, M., Alausa Waheed, M. 2012. Perceived Job Insecurity, Sex and Age as Predictors of Turnover Intentions among Employees of Merged Banks. www.ajbms.org Asian Journal of Business and Management Sciences ISSN: 2047-2528 Vol. 2 No. 6 [69-79] 2012

Bhatla, Neeta. 2011. To study the Employee Engagement practices and its effect on employee performance with special reference to ICICI and HDFC Bank in Lucknow. International Journal of Scientific \& Engineering Research Volume 2, Issue 8, Auguest-2011 1 ISSN 2229-5518
Bosman, J., Rothmann, S. And Buitendach, Jh. 2005. Job Insecurity, Burnout And Work Engagement: The Impact Of Positive And Negative Affectivity Sa Journal Of Industrial Psychology, 2005, 31 (4), 48-56 Sa Tydskrif Vir Bedryfsielkunde, 2005, 31 (4), $48-56$

Butali, Namasaka David; Wesang'ula, Poipoi Moses; Mamuli, Laura Catherine. 2013. Effects of Staff Turnover on the Employee Performance of Work at Masinde Muliro University of Science and Technology. International Journal of Human Resource Studies ISSN 2162-3058 2013, Vol. 3, No. 1

Miller, J.S., Cardy, R.L., \& Ellis, A.D. 2007. Employee equity: Toward a person-based approach to HRM. Human Resource Management Review, 17: 140151.

Carmeli, A., and Weisberg, J. (2006), 'Exploring Turnover Intentions Among Three Professional Groups of Employees,' Human Resource Development International, 9, 191-206.

Crabtree, S. (January 13, 2005). Engagement keeps the doctor away. Gallup Management Journal. Retrieved August 1, 2005, from http://gmj.gallup.com.

Crim, Dan; Seijts, Gerard. 2006. What Engages Employees The Most Or, The Ten C's Of Employee Engagement And The Workplace. Share On Email email Share On Twittershare On Twitter Share On Facebookpost To Facebook Share On Linkedinshare On Linkedin Share On Delicioussave To Delicious Share On Instapapersave To Instapaper

Davoudi, Seyed Mehdi Mousavi; Fartash, Kiarash; Allahyari, Meysam and Yarahmadi, Hamidreza. 2013. Workplace Bullying and Turnover Intentions among Iranian Employees. International Journal of Research in Organizational Behavior and Human Resource Management, Vol. 1, No. 1, 2013, pp. 12-23. ISSN 2320-8724

De Lange, A., De Witte, H., and Notelaers, G. (2008), 'Should I Stay or Should I Go? Examining Longitudinal Relations Among Job Resources and Work Engagement for Stayers Versus Movers,' Work \& Stress, 22, 3, 201-223.

Dessler, Gary (2010), Manajemen Sumber Daya Manusia, edisi 10 jilid 1, Jakarta: PT. Indeks

Field, L.K., \& Buitendach, J.H. (2011). Happiness, work engagement and organisational commitment of support staff at a tertiary education institution inSouth Africa. SA Journal of Industrial Psychology/SA Tydskrif vir Bedryfsielkunde, 
37(1), Art. $\quad \# 946$,
pages.doi:10.4102/sajip.v37i1.946

Gallup (2005) Employee engagement index survey, Gallup Management Journal http:suite101.com/article/what-is-anengagedemployee- a214893\#1xzz20NoBcpwi

Greenglass, E. R., Burke, R. dan Fiksenbaum, L., (2002), Impact of Restructuring, Job Insecurity and Job Satisfaction in Hospital Nurses, Stress News, January, 14(1):1-7

Halbesleben, J.R.B., and Wheeler, A.R. (2008), 'The Relative Roles of Engagement and Embeddedness in Predicting Job Performance and Intention to Leave,' Work \& Stress., 22, 3, 242-256.

Hussain, I. A.; Yunus, N.; Ishak, N. A. \& Daud N. 2013. The Influence of Intention to Leave Towards Employee Engagement among Young Bankers in Malaysia International Journal of Business and Management; Vol. 8, No. 14; 2013 ISSN 18333850 E-ISSN 1833-8119 Published by Canadian Center of Science and Education

Janine du Plooy; Gert Roodt (2010). Work engagement, burnout and related constructs as predictors of turnover intentions. SA Journal of Industrial Psychology; Vol 36, No 1 (2010), 13 pages. doi: 10.4102/sajip.v36i1.910

Nurita Juhdi, Fatimah Pa'wan, Ram Milah Kaur Hansaram. 2013. HR practices and turnover intention: the mediating roles of organizational commitment and organizational engagement in a selected region in Malaysia. The International Journal of Human Resource Management, 2013 Vol. 24, No. 15, 3002-3019, http://dx.doi.org/10.1080/ 09585192. 2013.763841

Kaifi A.Belal, Noori A. Selaiman (2011), Organizational Behavior: A Study on Managers, Employees, and Teams, Journal of Management Policy and Practice vol. 12(1) 2011

Khan, Farah and Ali, Uzma. 2013. A Cross-Cultural Study: Work Stress as Mediator between Job Satisfaction and Intention to Quit International Journal of Business and Social Science Vol. 4 No. 9; August 2013

Katie Truss, Angela Baron, Doug Crawford, Tom Debenham, Mike Emmott, Stephen Harding, Matthew Longman, Eti Murray, Peter Totterdill. 2013. Job Design And Employee Engagement. http://www.engageforsuccess.org/ wpcontent/uploads/ 2013/05/Job-Design-andEmployee-Engagement.pdf.

Little, P., \& Little, B. (2006). Employee engagement: conceptual issues. Journal of Organizational
Culture, Communications and Conflict, 10(1), 111-120.

Lockwood, Nancy R. 2007. Leveraging Employee Engagement for Competitive Advantage: HR's Strategic Role. 2007 SHRM® Research Quarterly

Makhbul, Zafir Mohd And Rahid, Mohd Radzuan, Fazilah Mohamad Hasun, 2011. The Correlation Analysis Proved That The Intention To Quit Among The Workers. Journal Of Global Management Volume 1. Number 1.

Mani, Vijaya. 2011. Analysis of Employee Engagement and its Predictors. International Journal of Human Resource Studies ISSN 2162-3058 2011, Vol. 1, No. 2

Mangi, Riaz Ahmed, Jalbani Amanat Ali. 2013. Mediation of Work Engagement between Emotional Exhaustion, Cynicism and Turnover Intentions. International Journal of Management Sciences and Business Research, 2013, ISSN (2226-8235) Vol-2, Issue 7

Markey, Ray; Ravenswood, Katherine; and Webber, Don J.. 2012. The impact of the quality of the work environment on employees' intention to quit. Economics Working Paper Series 1220 (2012)

Markos, Solomon and Sridevi, M. Sandhya. 2010. Employee Engagement: The Key to Improving Performance. International Journal of Business and Management Vol. 5, No. 12; December 2010

Maslach, C., Schaufeli, W.B. and Leiter, M.P. (2001), "Job burnout", Annual Review of Psychology, Vol. 52, pp. 397-422.

Mathis, Robert L dan John H Jackson. 2006. Human Resource Management, edisi 10. Salemba Empat, Jakarta.

Mathis, Robert L dan John H Jackson (2009). Human Resource Management. (12th ed.). Mason, $\mathrm{OH}$ :Thomson South-Western.

Mishra, Deepa; Kapse, Sampada; and Bavad Dhara. 2013. Employee Engagement at Banks in Kutch. International Journal of Application or Innovation in Engineering \& Management (IJAIEM) Volume 2, Issue 7, July 2013 ISSN 2319 - 4847

Mondy R. Wayne (2008), Manajemen Sumber Daya Manusia, edisi 10 jilid 1, Jakarta: Erlangga

Mxenge, S.V., M.Dywili, S. Bazana (2014) Job Engagement And Employees' Intention To Quit Among Administrative Personnel At The University Of Fort Hare In South Africa. International Journal Of Research In Social Sciences (C) 2013-2014 Ijrss \& K.A.J. All Rights 
Reserved. Sept. 2014. Vol. 4, No.5 Issn 2307$227 x$.

Newstrom, J. W. and Davis, K. (2002). Organizational Behaviour. "Human Behaviour at Work." 11th Edition: New Delhi Tata Mcgraw - Hill Publishing Company Limited.

Pareek, U. (2004). Understanding Organizational Behaviour. London: Oxford University Press.

Peryyer, C., Jordan, C., Firns, I., and Travaglione, A. (2010), Predicting Turnover Intentions, Management Research Review, 33, 9, 911-923.

Presti, Alessandro Lo; Nonnis, Marcello. 2012. Moderated Effects Of Job Insecurity On Work Engagement And Distress. TPM Vol. 19, No. 2, June 2012 - 97-113 - doi:10.4473/ TPM19.2.3 (C) 2012 Cises

Pushpakumari, M. D. (2008). The Impact of Job Satisfaction on Job Performance: An Empirical Analysis, 89-105. Retrieved in 11-11-2012, from http://202.11.2.113/SEBM/ronso/no9_1/08_PUS HPAKUMARI.pdf.

Robbins P. Stephens - Judge A. Timothy (2012), Perilaku Organisasi Buku 1 dan 2. edisi 12 Jakarta: Salemba Empat

Robinson, D., Perryman, S. and Hayday, S. (2004) The Drivers of Employee Engagement.Brighton, Institute for Employment Studies.

Schalkwyk, Van S., Du Toit, D.H., Bothma, A.S., \& Rothmann, S. 2010. Job insecurity, leadership empowerment behaviour, employee engagement and intention to leave in a petrochemical laboratory. SA Journal of Human Resource Management/SA Tydskrif vir Menslikehulpbronbestuur, 8(1), Art. \#234, 7 pages. DOI: 10.4102/sajhrm.v8i1.234

Stander, M.W., \& Rothmann, S. 2010. Psychological empowerment, job insecurity and employee engagement. SA Journal of Industrial

Sundaray, Bijaya Kumar. 2011. Employee Engagement: A Driver of Organizational Effectiveness.
European Journal of Business and Management www.ISSN 2222-1905 (Paper) ISSN 2222-2839 (Online) Vol 3, No.8, 2011

Tan, J., Tan, V., \& Tiong, T. N. (2007). Work Attitude, Loyalty, and Employee Turnover. Retrieved April 4, 2008, from http://www.entrepreneur.com/ tradejournals/article/ print/164421459.html

Vance, R.J. (2006), Employee Engagement and Commitment: A Guide to Understanding, Measuring, and Increasing Engagement in your Organization. SHRM Foundation's Practice Guidelines. http://www.shrm.org/about/foundation/news/Doc uments/1006 Employee EngagementOnlineReport.doc

Wegner, Patrice M. 2011. The Relationship Between Employee Engagement and Employee Retention in an Acute Healthcare Hospital. MA, Central Michigan University, 2005

Windya Novita. 2008. 13 Jurus Jitu Sukses di Dunia Kerja karya. Jakarta: Daras Books

Yavas, U. and Babakus, E. (2010), Relationships between organizational support, customer orientation, and work outcomes: a study of frontliner bank employees, International Journal of Bank Marketing, Vol. 28 No. 3, pp. 222-38.

http://economy.okezone.com/read/2013/05/12/279/80562 2/kompetisi-usaha-dan-war-for-talent

http://female.kompas.com/read/2009

http://www.infobanknews.com/2010/04/hasil-riset-mrikualitas-pelayanan-prima-perbankan-menurun/

https://www.i-1m.com/Insight/Edge/2013/May/discretionaryeffort-going-the-extra-mile

http://stephenjgill.typepad.com/performance_improveme nt_b/2009/06/employee-engagement-is-notemployee-commitment.html\#sthash.ohAnJpkW.dpuf. 